\title{
HUBUNGAN STATUS GIZI DAN FREKUENSI MENYUSUI DENGAN KELANCARAN ASI PADA IBU POST PARTUM DI PUSKESMAS SUKORAME KEDIRI
}

\author{
Siska Nawang Ayunda Maqfiro, Rina Wahyuning Tyas \\ Poltekkes Kemenkes Malang, Prodi Sarjana Terapan Kediri \\ Jalan KH. Wakhid Hasyim No.64B Kediri \\ Email: siskanawang303@gmail.com
}

\begin{abstract}
Relationship between Nutritional Status And Breastfeeding Frequency With Smoothness Breastmilk of Post Partum Mother in Puskesmas Sukorame Kediri.
\end{abstract}

Abstrack: Breastfeeding babies in Indonesia has become a culture but the practice of breastfeeding is still far from expected. The nutritional status of breastfeeding mothers and the frequency of breastfeeding is one of the factors that influence the quantity and quality of breast milk. The problem that arises is that there are still many mothers who experience ASI not smoothly. The purpose of this study was to determine the relationship of nutritional status and frequency of breastfeeding with the smooth operation of breast milk in post partum mothers in Puskesmas Sukorame Kediri. This study was a type ofstudy correlation analytic. The population in this study was 102 and the samples in this study were 37 respondents. Sampling uses purposive sampling technique. Data collection is done using a questionnaire. The collected data is then processed and analyzed using computer programs. Data analysis included bivariate analysis with thetest Spearman rho with $\alpha=0.05$. The results showed that there was a relationship between nutritional status and the smoothness of breast milk, obtained $\rho$ value $=0.043$ and $\alpha=0.05$ so that $0.043<0.05$ and there was a relationship between the frequency of breastfeeding and the smoothness of breast milk, obtained $\rho$ value $=0,000$ and $\alpha=005$ so that 0,000 $<0,05$. The conclusion of the study is that nutritional status and frequency of breastfeeding affect the smoothness of breast milk, mothers should pay attention to their nutritional status and breastfeed their babies as often as possible to get maximum results.

Keywords: Nutritional status, frequency of breastfeeding, smooth breastfeeding

\begin{abstract}
Abstrak : Menyusui bayi di Indonesia sudah menjadi budaya namun praktik pemberian ASI masih jauh dari yang diharapkan. Status gizi ibu menyusui dan frekuensi menyusui merupakan salah satu faktor yang mempengaruhi kuantitas dan kualitas ASI. Masalah yang muncul yaitu masih banyaknya ibu yang mengalami ASI tidak lancar. Tujuan penelitian ini adalah untuk mengetahui hubungan status gizi dan frekuensi menyusui dengan kelancaran ASI pada ibu post partum di Puskesmas Sukorame Kediri. Penelitian ini merupakan jenis penelitian analitik korelasi dengan jumlah populasi 102 dan jumlah sampel 37 responden. Pengambilan sampel menggunakan teknik purposive sampling. Analisis data mencakup analisis bivariat dengan uji spearman rho dengan $\alpha=0,05$. Hasil penelitian menunjukkan bahwa ada hubungan antara status gizi dengan kelancaran ASI, didapatkan $\rho$ value $=$ 0,043 dan $\alpha=0,05$ sehingga $0,043<0,05$ dan ada hubungan antara frekuensi menyusui dengan kelancaran ASI, didapatkan $\rho$ value $=0,000$ dan $\alpha=0,05$ sehingga $0,000<0,05$. Kesimpulan penelitian adalah status gizi dan frekuensi menyusui mempengaruhi kelancaran ASI, sebaiknya ibu harus memperhatikan status gizinya dan lebih sering menyusui bayinya untuk mendapatkan ASI yang maksimal.
\end{abstract}

Kata Kunci : Status gizi, Frekuensi menyusui, Kelancaran ASI 


\section{PENDAHULUAN}

Air Susu Ibu (ASI) adalah makanan utama bayi yang merupakan hasil sekresi payudara ibu dalam bentuk emulsi lemak dalam larutan protein, laktosa dan garam-garam organik. Dalam ASI terkandung enzim pencerna susu sehingga organ pencernaan bayi mudah mencerna dan menyerap gizi ASI (Arief, 2009).

Kebutuhan nutrisi selama menyusui meningkat karena untuk kecukupan produksi ASI untuk menyusui bayinya. Apabila nutrisi selama menyusui yang mencakup energi, protein, vitamin, mineral, lemak zat besi, asam folat, dan kalsium tidak terpenuhi maka dapat menimbulkan masalah dalam menyusui sehingga akan mengurangi produksi ASI (Roesli, 2010).

Sesuai dengan program peningkatan pemberian ASI peningkatan pengetahuan kesehatan masyarakat sangat diperlukan dalam upaya meningkatkan pemberian ASI, diantaranya adalah meningkatkan pengetahuan tentang frekuensi menyusui untuk meminimalkan terjadinya penyulit pada proses laktasi yaitu dengan menyusui bayinya sesering mungkin (Marmi, 2011).

Berhentinya proses menyusui pada ibu post partum di Indonesia disebabkan produksi ASI yang tidak lancar, sekitar $57 \%$ dengan jumlah kejadian menurut Perinasia (2010) adalah sebesar 675.650 kejadian.

Data kejadian penyulit laktasi di Jawa Timur diketahui seluruh ibu menyusui pada tahun 2010 adalah 1,2 juta orang dan 6,5\% diantaranya pernah mengalami penyulit laktasi, dan 50\% lebih disebabkan oleh produksi ASI yang tidak lancar sehingga berdampak pada kegagalan laktasi. Berdasarkan studi pendahuluan yang dilakukan di Puskesmas Sukorame Kota Kediri pada bulan Oktober 2017 terhadap $10 \mathrm{ibu}$ post partum 7 diantaranya ASI lancar sedangkan 3 ASI tidak lancar. Hal ini menunjukkan bahwa terjadinya ketidak lancaran pengeluaran ASI pada ibu post partum di Puskesmas Sukorame Kediri masih rentan.

Hisapan bayi, ketenangan jiwa dan pikiran ibu, usia kehamilan saat melahirkan, proses bersalin, penggunaan kontrasepsi, personal hygiene pada payudara, keterampilan dalam pemberian ASI, konsumsi rokok, status gizi, dan frekuensi menyusui dapat menjadi faktor yang mempengaruhi kelancaran ASI (Rahayu, 2012). Status gizi saat persalinan berkaitan dengan status gizi pada waktu konsepsi, juga berdasarkan keadaan sosial dan ekonomi saat kehamilan, pekerjaan, asupan nutrisi, dan penyakit infeksi yang pernah diderita. Status gizi ibu akan mempengaruhi status gizi janin dalam kandungan dan mempengaruhi taksiran berat lahirnya. Sering ditemui kendala ibu post partum tidak memproduksi ASI yang cukup, karena ibu kurang percaya diri bahwa ASInya cukup untuk bayinya sehingga mengakibatkan kurangnya frekuensi menyusui (Ebraim, 2002)

Kegagalan dalam proses menyusui sering disebabkan timbulnya beberapa masalah, baik masalah pada ibu maupun pada bayi, tetapi terkadang kegagalan menyusui dianggap karena bayinya yang tidak mau menyusu (Widiasih, 2008). Masalah dari ibu yang timbul selama menyusui dapat dimulai sejak sebelum persalinan (periode antenatal), pada masa awal pasca persalinan, dan beberapa waktu setelah persalinan. Untuk menghindari permasalahan perlu di perhatikan frekuensi menyusui dan cara meletakkan bayi pada payudara ketika menyusui berpengaruh terhadap keberhasilan menyusui. Proses menyusui jika frekuensi menyusui kurang maka produksi ASI menjadi tidak lancar, produksi ASI yang tidak lancar menyebabkan bayi menghisap dengan keras sehingga menyebabkan puting susu lecet. Kondisi ini mendorong terjadinya kegagalan pemberian ASI secara rutin (Ramalah, 2009).

Mengingat pemberian ASI adalah sangat penting maka diperlukan perilaku baik dari ibu dalam mengatasi masalah kelancaran ASI dengan cara sering menyusui bayinya. ASI biasanya akan keluar di hari ke-3 pos partum dengan jumlah sekitar $50 \mathrm{ml}$ (kurang lebih 3 sendok makan), bila hal ini tidak diketahui baik oleh ibu maka ibu akan menghentikan pemberian ASI kepada bayi (Astutik, 2014). Dampak pada bayi adalah meningkatnya pemberian makanan pengganti ASI, sementara pencernaan bayi (terutama pada kelahiran kurang bulan) belum siap menerima, sehingga akan mengalami gangguan gizi. 
Berdasarkan data dan fenomena diatas, maka peneliti tertarik untuk melakukan penelitian dengan judul "Hubungan Status gizi dan Frekuensi Menyusui dengan Kelancaran ASI Pada Ibu Post Partum di Puskesmas Sukorame Kediri.

\section{METODE PENELITIAN}

Desain dalam penelitian ini adalah penelitian analitik menggunakan studi korelasi dengan pendekatan cross sectional.

Populasi dalam penelitian ini adalah $51 \mathrm{ibu}$ post partum yang berada di wilayah kerja Puskesmas Sukorame Kediri bulan Nopember Tahun 2017. Sampel dalam penelitian ini adalah sebagian ibu post partum yang ada di Puskesmas Sukorame Kediri Tahun 2017 sebanyak 37 responden yang memenuhi kriteria insklusi dan ekslusi. Kriteria inklusi yang akan dijadikan acuan dalam penelitian ini adalah: Ibu yang bersedia menjadi responden dan Ibu yang bisa baca tulis. Sedangkan kriteria eksklusi : Ibu yang tidak kooperatif, ibu yang mempunyai masalah menyusui seperti, puting susu lecet, bendungan ASI, mastitis, ibu dengan gangguan psikologis, bayi dengan cacat bawaan labio palatoscisis. Teknik pengambilan sampel pada penelitian ini menggunakan teknik nonprobability sampling, dengan jenis pengambilan sampel menggunakan metode purposive sampling.

Variabel independen dalam penelitian ini adalah status gizi dan frekuensi menyusui, sedangkan variabel dependen adalah kelancaran ASI.

Penelitian ini dilakukan pada bulan Nopember 2017. Instrumen yang digunakan dalam penelitian ini untuk memperoleh data penelitian dengan menggunakan kuesioner dan lembar observasi.

Selanjutnya data dianalisa menggunakan Spearman Rank.

\section{HASIL PENELITIAN}

Hasil penelitian ini akan disajikan hasil dari analisis univariate dan analisis bivariate.
Tabel 1.1 Distribusi frekuensi responden berdasarkan status gizi di Puskesmas Sukorame Kediri

\begin{tabular}{cccc}
\hline No & Status Gizi & Frekuensi & Persentase \\
\hline 1 & Kurang & 1 & 2,7 \\
2 & Normal & 21 & 56,8 \\
3 & Overweight & 13 & 35,1 \\
4 & Obesitas & 2 & 5,4 \\
\hline & Total & 37 & 100,0 \\
\hline
\end{tabular}

Berdasarkan tabel di atas dapat diinterpretasikan sebagian besar yaitu $21 \quad(56,8 \%)$ responden memiliki status gizi normal.

Tabel 1.2 Distribusi frekuensi responden berdasarkan frekuensi menyusui di Puskesmas Sukorame Kediri

\begin{tabular}{cccc}
\hline No & Frekuensi & & \\
\hline 1 & Menyusui & Frekuensi & Persentase \\
2 & Demand & 11 & 29,7 \\
& Total & 37 & 70,3 \\
\hline
\end{tabular}

Berdasarkan tabel di atas dapat diinterpretasikan bahwa sebagian besar yaitu $26 \quad(70,3 \%)$ responden menyusui secara demand atau terjadwal. 
Tabel 1.3 Distribusi frekuensi responden berdasarkan kelancaran ASI di Puskesmas Sukorame Kediri

\begin{tabular}{cccc}
\hline No & Kelancaran ASI & Frekuensi & Persentase \\
\hline 1 & Lancar & 18 & 48,6 \\
2 & Tidak Lancar & 19 & 51,4 \\
\hline & Total & 37 & 100,0 \\
\hline
\end{tabular}

Berdasarkan sebagian besar yaitu 19 $(51,4 \%)$ responden mengalami ASI lancar.

Tabel 1.4 Hasil tabulasi silang hubungan antara status gizi dengan kelancaran ASI di Puskesmas Sukorame Kediri

\begin{tabular}{lcccccc}
\hline & \multicolumn{5}{c}{ Kelancaran ASI } \\
Status gizi & \multicolumn{2}{c}{ Lancar } & \multicolumn{2}{c}{ Tidak } \\
& \multicolumn{7}{c}{ lancar } & Total \\
& $\mathrm{F}$ & $\%$ & $\mathrm{~F}$ & $\%$ & $\mathrm{~F}$ & $\%$ \\
\hline Kurang & 0 & 0 & 1 & 2,7 & 1 & 2,7 \\
Normal & 14 & 37,8 & 7 & 18,9 & 21 & 56,7 \\
Overweight & 4 & 10,8 & 9 & 24,3 & 13 & 35,1 \\
Obesitas & 0 & 0 & 2 & 5,4 & 2 & 5,4 \\
Total & 18 & 48,6 & 19 & 43,2 & 37 & 100 \\
\hline Corelation & Coefficient $=$ & $\alpha=0,05$ & $\rho$ value $=$ \\
0,334 & & & \multicolumn{5}{c}{0,043} \\
\hline
\end{tabular}

Berdasarkan hasil uji statistik Spearman rho antara status gizi dengan kelancaran ASI didapatkan $\rho$ value $=0,043$ lebih kecil dari nilai $\alpha=0,05(0,043<0,05)$ sehingga $\mathrm{H}_{0}$ ditolak dan $\mathrm{H}_{1}$ diterima, artinya ada hubungan antara status gizi dengan kelancaran ASI di Puskesmas Sukorame Kediri. Sedangkan nilai koefisien korelasinya 0,334 yang berarti terdapat hubungan yang cukup kuat antara status gizi dengan kelancaran ASI di Puskesmas Sukorame Kediri.
Tabel 1.5 Hasil tabulasi silang hubungan antara frekuensi dengan kelancaran ASI di Puskesmas Sukorame Kediri

\begin{tabular}{lccccccc}
\hline Frekuensi & \multicolumn{7}{c}{ Lelancaran ASI } \\
Menyusui & \multicolumn{5}{c}{$\begin{array}{c}\text { Tidak } \\
\text { lancar }\end{array}$} & Total \\
& $\mathrm{F}$ & $\%$ & $\mathrm{~F}$ & $\%$ & $\mathrm{~F}$ & $\%$ \\
\hline On demand & 11 & 29,7 & 0 & 0 & 11 & 29,7 \\
Demand & 7 & 18,9 & 19 & 51,3 & 26 & 70,2 \\
Total & 18 & 56,7 & 19 & 51,3 & 37 & 100 \\
\hline Corelation & Coefficient & $=$ & $\alpha=0,05$ & $\rho$ value $=$ \\
0,668 & & & & \multicolumn{2}{c}{0,000} \\
\hline
\end{tabular}

Berdasarkan hasil uji statistik Spearman rho antara frekuensi menyusui dengan kelancaran ASI didapatkan $\rho$ value $=0,000$ lebih kecil dari nilai $\alpha=0,05(0,000<0,05)$ sehingga $\mathrm{H}_{0}$ ditolak dan $\mathrm{H}_{1}$ diterima, artinya ada hubungan antara frekuensi menyusui dengan kelancaran ASI di Puskesmas Sukorame kediri tahun 2015. Sedangkan nilai koefisien korelasinya 0,668 yang berarti terdapat hubungan yang sangat kuat antara frekuensi menyusui dengan kelancaran ASI di Puskesmas Sukorame Kediri.

\section{PEMBAHASAN}

\section{Status Gizi}

Berdasarkan hasil penelitian didapatkan dari total 37 responden sebagian besar yaitu 21 $(56,8 \%)$ responden memiliki status gizi normal. Status gizi merupakan keseimbangan antara status kebutuhan dan pemenuhan nutrisi. Ibu yang memiliki gizi baik akan mampu memproduksi ASI sehingga ASI bisa keluar dengan lancar karena kebutuhan gizi yang cukup. ASI yang lancar baik untuk memenuhi kebutuhan gizi pada bayi sehingga gizi bayi akan tercukupi (Beck, 2012).

Banyaknya ibu yang memiliki status gizi normal ditempat penelitian menunjukkan ibu sudah mengerti tentang pentingnya status gizi pada ibu menyusui. Dengan memiliki status gizi yang baik maka akan mencegah timbulnya masalah status gizi karena status gizi akan mempengaruhi juga terhadap kelancaran ASI. Jika ASI yang keluar tidak lancar maka kebutuhan gizi pada bayi juga tidak akan tercukupi. Tenaga kesehatan sangat perlu memberikan informasi tentang gizi ibu menyusui 
sehingga lebih banyak lagi ibu yang mengerti tentang gizi ibu menyusui dan bagi ibu yang masih memiliki masalah tentang gizi dapat meningkatkan pemenuhan kebutuhan nutrisinya.

\section{Frekuensi menyusui}

Hasil penelitian didapatkan dari total 37 responden sebagian besar yaitu 26 (70,3 \%) responden menyusui secara demand atau terjadwal.

Frekuensi menyusui adalah berapa kali ibu menyusui dalam satu hari. Ibu sebaiknya tidak menjadwalkan pemberian ASI. Menyusui terbaik secara on demand pagi maupun malam 8 sampai 12 kali dalam sehari. Makin jarang bayi disusui, biasanya ASI tidak lancer sehingga kelancaran ASI sangat dipengaruhi oleh seringnya bayi menyusu. (Wiji, 2013).

Masih banyaknya ibu yang menyusui secara terjadwal dilatar belakangi oleh pendidikan dan pekerjaan ibu. Hal ini berpengaruh terhadap kemampuan ibu dalam menerima informasi tentang frekuensi menyusui yang berdampak pada banyaknya ibu yang masih menjadwalkan dalam menyusui bayinya. Responden yang bekerja di bidang swasta akan banyak menghabiskan waktunya untuk pekerjaannya, sehingga tidak memiliki waktu untuk menyusui bayinya.

Banyaknya ibu yang menyusui bayinya secara terjadwal ditempat penelitian menunjukkan ibu belum mengerti tentang pentingnya menyusui sesuai kebutuhan bayinya. Dengan menyusui secara terjadwal, tidak sesuai kebutuhan bayi akan menimbulkan masalah menyusui. Tenaga kesehatan sangat perlu memberikan informasi tentang frekuensi menyusui kepada ibu sehingga lebih banyak lagi ibu yang mengerti tentang frekuensi menyusui dan dapat menyusui bayinya dengan baik sesuai kebutuhan bayi.

\section{Kelancaran ASI}

Hasil penelitian didapatkan dari total 37 responden sebagian besar yaitu 19 (51,4 \%) responden mengalami ASI tidak lancar.

Kelancaran pengeluaran ASI ditandai dengan ASI keluar saat payudara ditekan, ASI merembes karena payudara penuh, dan ASI menetes saat bayi tidak sedang menyusu. Semakin sering bayi disusui maka akan mempengaruhi kelancaran ASI sehingga ASI bisa keluar dengan lancar karena setiap hisapan bayi akan menghasilkan oksitosin sehingga payudara akan terus memproduksi ASI (Suradi, 2008). Ibu yang masih mengalami ASI yang tidak lancar dipengaruhi oleh pendidikan dan pekerjaan ibu, sehingga ibu masih memiliki informasi tentang kelancaran ASI yang kurang yang berdampak pada banyaknya ibu yang masih mengeluh ASI tidak lancar. Responden yang bekerja dibidang swasta akan banyak menghabiskan waktunya untuk pekerjaannya dan tidak memiliki waktu untuk menyusui bayinya sehingga akan mempengaruhi kelancaran ASI.

Banyaknya ibu yang mengalami ASI tidak lancar ditempat penelitian menunjukkan bahwa ibu belum mengerti tentang kelancaran ASI. Ibu yang sering menyusui bayinya atau sesuai kebutuhan bayi akan memperlancar pengeluaran ASI. Tenaga kesehatan sangat perlu memberikan informasi tentang kelancaran ASI dan cara agar ASI bisa keluar dengan lancar kepada ibu sehingga lebih banyak lagi ibu yang dapat menyusui dengan lancar.

\section{Hubungan antara status gizi dengan kelancaran ASI pada ibu post partum di Puskesmas Sukorame Kediri}

Hasil penelitian yang disajikan dalam tabulasi silang menunjukkan bahwa dari total 37 responden dari total 37 responden hampir setengah dari responden yaitu $14 \quad(37,8 \%)$ memiliki status gizi normal dan ASI lancar.

Hasil uji statistik Spearman rho antara status gizi dengan kelancaran ASI didapatkan $\rho$ value $=0,043$ lebih kecil dari nilai $\alpha=0,05$ $(0,043<0,05)$ sehingga $\mathrm{H}_{0}$ ditolak dan $\mathrm{H}_{1}$ diterima, artinya ada hubungan antara status gizi dengan kelancaran ASI di Puskesmas Sukorame Kediri. Sedangkan nilai koefisien korelasinya 0,334 yang berarti terdapat hubungan yang cukup kuat antara status gizi dengan kelancaran ASI di Puskesmas Sukorame Kediri.

Salah satu faktor yang mempengaruhi kelancaran ASI adalah status gizi. Status gizi merupakan status kesehatan yang ditandai 
dengan keseimbangan antara status kebutuhan dan input nutrisi. Ibu yang memiliki gizi baik akan mampu memproduksi ASI sehingga ASI bisa keluar dengan lancar karena kebutuhan gizi yang cukup. ASI yang lancar baik untuk memenuhi kebutuhan gizi pada bayi sehingga gizi bayi akan tercukupi (Beck, 2012).

Pada ibu menyusui sebaiknya memperhatikan pola makannya agar memiliki gizi yang cukup. Ibu yang memiliki gizi yang cukup akan lebih banyak produksi ASInya dibandingkan ibu yang memiliki gizi kurang atau obesitas. Ibu yang memiliki gizi kurang akan mengalami masalah dalam menyusui karena payudara susah memproduksi ASI begitu juga ibu yang obesitas, ibu yang obesitas akan mengalami masalah dalam menyusui karena terlalu banyak lemak didalam tubuh sehingga ASI susah untuk keluar.

Fakta dan teori ditempat penelitian menunjukkan bahwa ibu yang memiliki status gizi normal tinggi akan mempengaruhi pengeluaran ASI. Hal ini dikarenakan kelancaran ASI sangat dipengaruhi oleh status ibu, semakin tinggi status gizi ibu maka ASI juga tidak akan keluar dengan lancar.

\section{Hubungan antara frekuensi menyusui dengan kelancaran ASI pada ibu post partum di Puskesmas Sukorame Kediri}

Hasil penelitian yang disajikan dalam tabulasi silang menunjukkan bahwa dari total 37 responden sebagian besar dari responden yaitu $19(51,3 \%)$ menyusui bayinya secara demand dan ASInya tidak lancar.

Hasil uji statistik Spearman rho antara frekuensi menyusui dengan kelancaran ASI didapatkan $\rho$ value $=0,000$ lebih kecil dari nilai $\alpha=0,05(0,000<0,05)$ sehingga $\mathrm{H}_{0}$ ditolak dan $\mathrm{H}_{1}$ diterima, artinya ada hubungan antara frekuensi menyusui dengan kelancaran ASI di Puskesmas Sukorame Kediri. Sedangkan nilai koefisien korelasinya 0,668 yang berarti terdapat hubungan yang sangat kuat antara frekuensi menyusui dengan kelancaran ASI di Puskesmas Sukorame Kediri.

Pemberian ASI yang baik adalah tidak terjadwal yaitu sesuai permintaan bayi minimal 8 kali per hari. Frekuensi menyusui mempengaruhi produksi ASI. Semakin jarang bayi disusui maka ASI yang keluar tidak lancar. Sedangkan rentang yang optimal dalam menyusui adalah antara 8 sampai 12 kali setiap hari (Wiji, 2013).

Sebaiknya bayi disusui secara tidak terjadwal (on demand). Ibu hendaknya segera menyusui bayinya apabila bayi menangis bukan karena sebab lain misalnya merasa kepanasan atau kedinginan, atau sekedar ingin didekap tetapi saat bayi menangis karena merasa lapar dan membutuhkan ASI.

Fakta dan teori ditempat penelitian menunjukkan bahwa ibu yang menyusui bayinya secara tidak terjadwal akan mempengaruhi kelancaran ASI. Hal ini dikarenakan kelancaran ASI sangat dipengaruhi oleh frekuensi menyusui ibu, makin jarang ibu menyusui bayinya maka ASI juga tidak akan keluar dengan lancar.

\section{DAFTAR PUSTAKA}

Arif, Nurhaeni. (2009). Panduan Ibu Cerdas ASI dan Tumbuh Kembang bayi.Yogyakarta: Media Pressindo.

Astutik, R.Y. 2014. Payudara dan Laktasi. Jakarta: Salemba Medika.

Beck, M. E. 2000. Ilmu Gizi dan Diet. Jakarta: Yayasan Essensial Medika

Ebraim, G.I. (2002). Air susu ibu. Yogyakarta : Yayasan Esentia Medica

Marmi. 2011. Asuhan Kebidanan pada Masa Nifas. Jakarta: Salemba Medika.

Per kumpulan Perinatologi Indonesia (PERINASIA). 2012. Manajemen

Laktasi Jakarta

Rahayu, D. P \& Mahanani, S. N. (2012). Faktorfaktor yang Mempengaruhi Produksi ASI pada Ibu Nifas. Jurnal diterbitkan. Kediri : STIKES RS. Baptis Kediri

Ramaiah, Savitri. 2009. ASI dan Menyusui:

Panduan Praktis bagi Ibu Setelah

Melahirkan. Jakarta: PT. Bhuana Ilmu Populer

Roesli, Utami. 2010. Bayi Sehat Berkat ASI Eksklusif. Jakarta: PT Elex Komputindo. 
Suradi, R. 2008. Bahan bacaan manajemen laktasi. Jakarta : Perinasia

Widiasih, Restuning. 2008. Masalah-masalah dalma menyusui. Universitas Padjajaran Bandung

Wiji, N Rizki. 2013. ASI dan Panduan Ibu Menyusui. Yogyakarta: Nuha Medika 